OPEN ACCESS

Edited by:

Ichiro Maruyama,

Okinawa Institute of Science and

Technology Graduate University,

Japan

Reviewed by:

Alexander Dietrich,

Ludwig-Maximilians-Universität

München, Germany

Tony Ngo,

University of California, San Diego,

United States

*Correspondence:

Noushafarin Khajavi

noushafarin.khajavi@charite.de

Specialty section:

This article was submitted to Molecular and Structural Endocrinology,

a section of the journal

Frontiers in Endocrinology

Received: 27 June 2017

Accepted: 28 July 2017

Published: 16 August 2017

Citation:

Khajavi N, Mergler S and

Biebermann H (2017)

3-lodothyronamine, a Novel

Endogenous Modulator of Transient Receptor Potential Melastatin 8?

Front. Endocrinol. 8:198. doi: 10.3389/fendo.2017.00198

\section{3-lodothyronamine, a Novel Endogenous Modulator of Transient Receptor Potential Melastatin 8?}

\author{
Noushafarin Khajavi ${ }^{1 *}$, Stefan Mergler ${ }^{2}$ and Heike Biebermann ${ }^{1}$ \\ ${ }^{1}$ Institute for Experimental Pediatric Endocrinology, Charité University of Medicine Berlin, Berlin, Germany, ${ }^{2}$ Department of \\ Ophthalmology, Charité University of Medicine Berlin, Berlin, Germany
}

The decarboxylated and deiodinated thyroid hormone $(\mathrm{TH})$ derivative, 3-iodothyronamine $\left(3-T_{1} A M\right)$, is suggested to be involved in energy metabolism and thermoregulation. G protein-coupled receptors (GPCRs) are known as the main targets for 3-T, $\mathrm{AM}$; however, transient receptor potential channels (TRPS) were also recently identified as new targets of 3-T $T_{1} A M$. This article reviews the current knowledge of a putative novel role of 3-T AM in the modulation of TRPs. Specifically, the TRP melastatin 8 (TRPM8) was identified as a target of 3-T,AM in different cell types including neoplastic cells, whereby 3-T,AM significantly increased cytosolic $\mathrm{Ca}^{2+}$ through TRPM8 activation. Similarly, the $\beta$-adrenergic receptor is involved in 3-T,AM-induced $\mathrm{Ca}^{2+}$ influx. Therefore, it has been suggested that 3-T, $\mathrm{AM}$-induced $\mathrm{Ca}^{2+}$ mobilization might be due to $\beta$-adrenergic receptor/TRPM8 channel interaction, which adds to the complexity of GPCR regulation by TRPs. It has been revealed that TRPM8 activation leads to a decline in TRPV1 activity, which may be of therapeutic benefit in clinical circumstances such as treatment of TRPV1-mediated inflammatory hyperalgesia, colitis, and dry eye syndrome. This review also summarizes the inverse association between changes in TRPM8 and TRPV1 activity after $3-T_{1} A M$ stimulation. This finding prompted further detailed investigations of the interplay between 3-T,AM and the GPCR/TRPM8 axis and indicated the probability of additional GPCR/ TRP constellations that are modulated by this TH derivative.

Keywords: 3-iodothyronamine, transient receptor potential channel, calcium, thermoregulation, inflammation

\section{INTRODUCTION}

Thyronamines (TAMs) are identified as a novel class of endogenous signaling compounds. Currently, two representatives of TAMs, known as 3-iodothyronamine (3- $\left.T_{1} A M\right)$ and thyronamine $\left(T_{0} A M\right)$, have been identified in vivo. Both compounds were detected in blood, heart, brain, thyroid, and many other tissues in rodents (1). Although endogenous TAM concentration may be lower compared to thyroid hormone (TH), it is noteworthy that the tissue-specific and subcellular distributions of TAMs are unknown. Therefore, the concentrations within different cell types might be higher than the average whole tissue concentrations measured.

3-Iodothyronamine is a decarboxylated and deiodinated TH metabolite (2-4). Administration of 3- $\mathrm{T}_{1} \mathrm{AM}$ in mice resulted in concentration-dependent reversible effects on body temperature, energy metabolism, and cardiac and neurological functions compared with vehicle-treated controls (1). The discovery of 3- $\mathrm{T}_{1} \mathrm{AM}$ and the profound pharmacological effects of this endogenous signaling compound have raised interest to elucidate its signaling properties $(1,3)$. It is now known that $3-T_{1} A M$ is 
a "multi-target" ligand, which affects $G$ protein-coupled receptors (GPCRs) and interacts with non-GPCR proteins (5). Classically, the first GPCR-target identified for 3-T $\mathrm{T}_{1} \mathrm{AM}$ was a member of the rhodopsin-like family of GPCRs known as trace amineassociated receptor 1 (TAAR1) (1) (Figure 1). Recently, several other GPCRs were identified as targets for 3- $\mathrm{T}_{1} \mathrm{AM}$, such as $\alpha 2 \mathrm{~A}$ adrenergic receptor (6) and $\beta 2$ adrenergic receptor (7) (Figure 1).

The overall aim of this review is to summarize the modulation of transient receptor potential channels (TRPs) through $3-\mathrm{T}_{1} \mathrm{AM}$. Here, we first review the signaling effects of $3-\mathrm{T}_{1} \mathrm{AM}$ and then focus on TRPs as potential targets for this TH metabolite. In particular, two thermo-TRPs, TRP melastatin 8 (TRPM8) and TRPV, are involved in $3-\mathrm{T}_{1} \mathrm{AM}$-induced $\mathrm{Ca}^{2+}$ mobilization. Interestingly, both of these TRPs are the key players in thermoregulation and also mediate inflammation in pathophysiological conditions. In this review, we also describe the $3-\mathrm{T}_{1} \mathrm{AM}$ action on a GPCR/TRP interplay and the possible inverse association between changes in different TRP channel activity modulated by this TH metabolite.

\section{3-T,AM DECLINES BODY TEMPERATURE IN RODENTS}

In vivo, 3- $\mathrm{T}_{1} \mathrm{AM}$ partially opposes effects of classical $\mathrm{TH}$ action, resulting in a variety of physiological responses (5). Intraperitoneal (ip) injection of 3-T $\mathrm{T}_{1} \mathrm{AM}$ blocks the hypothalamic-pituitarythyroid axis and was shown to reversibly decrease metabolic rate in rodents $(1,8)$. One of the most prominent effects of $3-\mathrm{T}_{1} \mathrm{AM}$ in rodents is temporary body temperature decline (1). In clinical settings, this TH metabolite is the only endogenous compound known to induce hypothermia and is additionally suggested to have therapeutic potential for the treatment and prevention of stroke. An ip injection of $3-\mathrm{T}_{1} \mathrm{AM}$ in adult mice after the experimental induction of stroke led to a reduction of infarct volumes compared with vehicle-treated control mice (9). Due to the profound effects of $3-\mathrm{T}_{1} \mathrm{AM}$ in vivo, an increasing number of studies over the last few years have been devoted to investigate the biosynthetic pathways, functions, and underlying mechanisms behind the effects of $3-\mathrm{T}_{1} \mathrm{AM}$.

\section{SIGNALING EFFECTS OF 3-T,AM}

Recent studies described the signaling properties of $3-\mathrm{T}_{1} \mathrm{AM}$ in various cell systems. Interestingly, one study revealed that the functional thyrotropin (TSH)-dependent iodide uptake and TSH-dependent mRNA of sodium/iodide symporter in rat thyrocytes were decreased in the presence of $3-\mathrm{T}_{1} \mathrm{AM}$. Therefore, it was congruent to investigate whether 3- $\mathrm{T}_{1} \mathrm{AM}$ modifies signaling pathways downstream of TSH receptor (TSHR) (10). TSH is the major regulator of thyroid function and activation of the TSHR results in Gs as well as Gq signaling in thyrocytes $(11,12)$. TSH elicits increases of intracellular $\mathrm{Ca}^{2+}$ concentration through activation of TSHR-mediated Gq signaling (13). This increase partially occurs through inositol 1,4,5-trisphosphate (IP3)-evoked release of $\mathrm{Ca}^{2+}$ sequestered in the endoplasmic reticulum (ER) (14). Previous studies demonstrated the expression of a member of the TRPC family of cation channels known as TRPC2 (pseudogene in human) in rat thyroid cells (15).

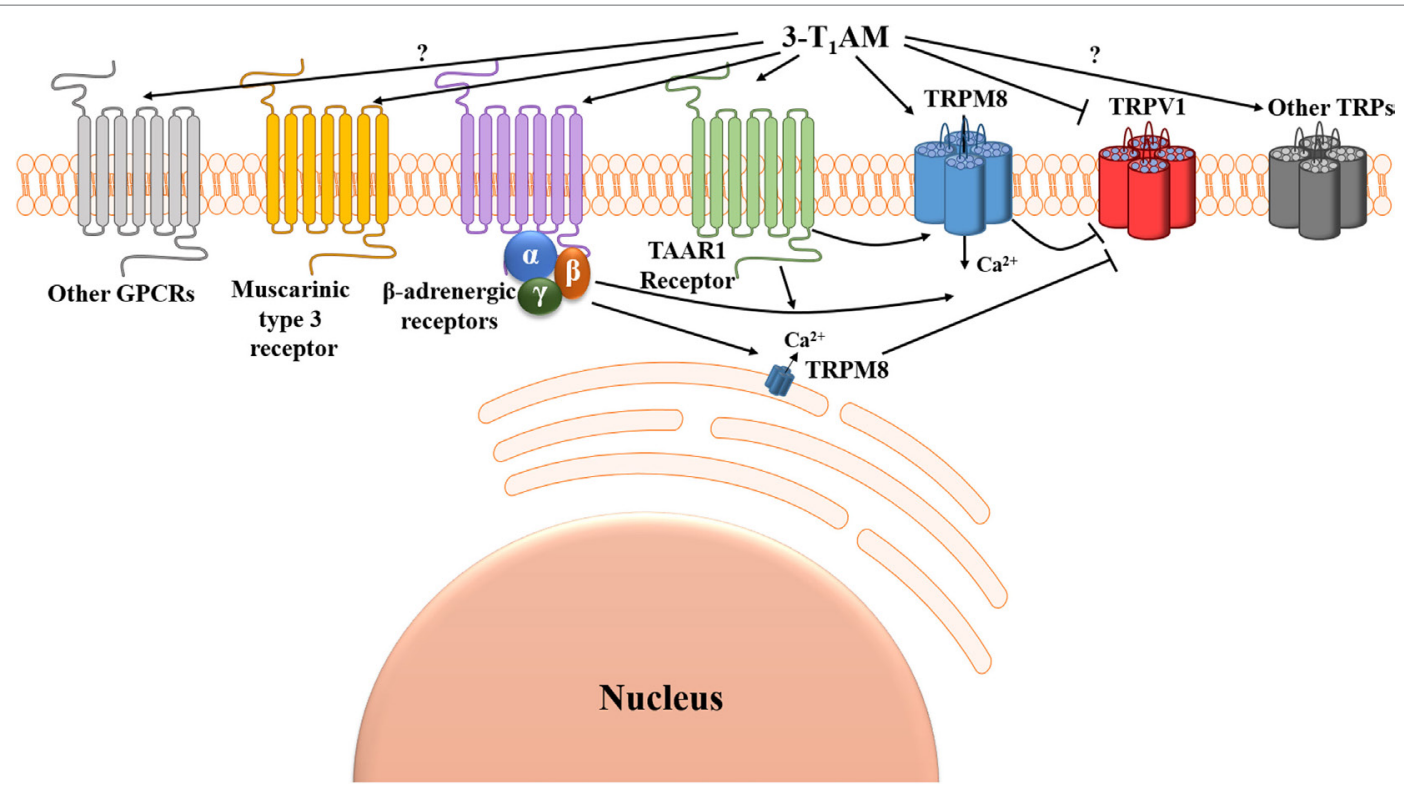

FIGURE 1 | Suggested $\mathrm{Ca}^{2+}$ signal transduction pathways induced by 3-iodothyronamine (3-T,AM). Two G protein-coupled receptors (GPCRs), known as trace amine-associated receptor 1 (TAAR1) and $\beta$-adrenergic receptors, can be activated and one GPCR known as muscarinic type 3 receptor can be suppressed by 3-T $\mathrm{T}_{1} \mathrm{AM}$. 3-T $\mathrm{TM}$ increases $\left[\mathrm{Ca}^{2+}\right]_{\mathrm{i}}$ via a member of the transient receptor channel superfamily known as transient receptor potential channel melastatin 8 (TRPM8) (menthol or cold receptor), and this effect is blocked by BCTC. 3-T,AM may either directly activate TRPM8 by a GPCR-independent mechanism or indirectly via the $\beta / \gamma$-subunits of Gi/o downstream of $\beta$-adrenergic receptors. TRPM8 activation by $3-\mathrm{T}_{1} \mathrm{AM}$ inhibits TRPV1 (capsaicin or heat receptor)-induced Ca ${ }^{2+}$ influx. Notably, 3-T, AM may also directly suppress TRPV1 by a GPCR-independent mechanism $\left(\downarrow\left[\mathrm{Ca}^{2+}\right]_{i}\right)$. So far, the involvement of other GPCRs and TRPs in 3-T,AM-induced signaling effects remained elusive. 
Surprisingly, reducing the expression of TRPC2 with shRNA decreased $\mathrm{Ca}^{2+}$ influx and increased the TSH-induced production of cAMP, which can be due to marked upregulation of TSHR. Nevertheless, this study could not rule out the possibility of $\mathrm{Gi}$ signaling inhibition. It has been suggested that deprivation of $\mathrm{Ca}^{2+}$ removes the inhibitory action on adenylyl cyclase (AC), upregulates pERK1/2, and increases TSHR expression in thyroid cells (15).

It is known that $3-T_{1} A M$ induces Gs/AC signaling in rat Taar1 and human TAAR1-transfected human embryonic kidney (HEK) cells $(1,16)$. Recently, it was demonstrated for the first time that $3-\mathrm{T}_{1} \mathrm{AM}$ increases intracellular $\mathrm{Ca}^{2+}$ concentration in rat thyrocytes (PCCL3 cells) (10). TSH-dependent activation of the Gs signaling pathway was not influenced by $3-\mathrm{T}_{1} \mathrm{AM}(10)$. Furthermore, there is currently no evidence that $3-\mathrm{T}_{1} \mathrm{AM}$ induced IP3 formation in thyrocytes (10). However, 3- $\mathrm{T}_{1} \mathrm{AM}$ induced increases in cytosolic $\mathrm{Ca}^{2+}$ under extracellular $\mathrm{Ca}^{2+}$ free conditions in epithelial cells, indicating the intracellular store depletion independent from Gq downstream signaling (17). Therefore, it was concluded that 3-T $\mathrm{T} A \mathrm{M}$ effect in thyrocytes is independent from TSH-induced Gs or Gq signaling (10).

Beside a function of $3-T_{1} A M$ on thyrocytes, it could be shown in another study that $3-\mathrm{T}_{1} \mathrm{AM}$ enhanced $\mathrm{Gs}$ signaling in response to isoprenaline (ISOP) stimulation of the $\beta 2$-adrenergic receptor in transfected HEK293 cells, but not of $\beta 1$-adrenergic receptor. Increasing concentrations of $3-\mathrm{T}_{1} \mathrm{AM}$ in combination with a constant concentration of ISOP modulated Gs-mediated cAMP accumulation. At high $3-\mathrm{T}_{1} \mathrm{AM}$ concentrations $\left(10^{-5}-10^{-6} \mathrm{M}\right)$, there was a weak increase in ISOP-stimulated cAMP accumulation. In contrast, at lower $3-\mathrm{T}_{1} \mathrm{AM}$ concentrations $\left(10^{-7}-10^{-8} \mathrm{M}\right)$, a significant increase in ISOP-induced cAMP accumulation was observed, which may be related to the activation of $G_{i}$ signaling (7). These findings in in vitro systems indicated that $3-\mathrm{T}_{1} \mathrm{AM}$ may have a differential impact on certain GPCRs, particularly aminergic receptors, and that the mode of action is concentration dependent. It may also indicate the possibility of biphasic activation (i.e., high and low concentrations may have similar actions, while moderate concentrations enact distinct effects) of different signaling pathways.

Taken together, these studies revealed that 3-T $\mathrm{AM}$ enhances GPCR-mediated downstream signaling in different cell types. In addition, $\beta 2$-adrenergic receptors have been suggested as a new GPCR target for 3-T $\mathrm{T}_{1} \mathrm{AM}$. Nevertheless, the underlying mechanism behind the $\mathrm{Ca}^{2+}$ signal transduction remained elusive.

\section{ION CHANNELS AS POTENTIAL TARGETS FOR 3-T,AM}

Although many studies have reported remarkable hypothermia caused by $3-\mathrm{T}_{1} \mathrm{AM}$, different observations demonstrated that this effect is not exclusively mediated via GPCRs. One study described that 3-T $\mathrm{T}_{1} \mathrm{AM}$-induced decrease of body temperature still persisted in mTaar1 knockout mice (5), which suggested that the actions of $3-\mathrm{T}_{1} \mathrm{AM}$ are not only mediated via the mTaar1 receptor for the induction of hypothermia (18). Recently, it has been shown that hypothermic effects of $3-\mathrm{T}_{1} \mathrm{AM}$ in mice are due to peripheral vasodilation and subsequent heat loss from the tail surface. Although the possible targets of 3-T 1 AM, Taar1, and the adrenergic receptors were detected in tail arteries and the aorta, neither vessel responded to high doses of 3-T $\mathrm{AM}$. As this anapyrexia effect was also found after intracerebroventricular injection, the authors concluded that this temperature effect might be mediated by non-GPCR targets such as TRPs in the hypothalamus (19). Notably, the systemic temperature lowering effect of $3-\mathrm{T}_{1} \mathrm{AM}$ lies within the range adequate for eliciting TRP activation. Application of specific blockers as well as overexpression system revealed the involvement of thermo-TRPs in 3-T $\mathrm{T}_{1} \mathrm{AM}$-induced effect. Table 1 summarizes the effects of $3-\mathrm{T}_{1} \mathrm{AM}$ on $\mathrm{Ca}^{2+}$ regulation and whole-cell currents in different cell types. Notably, 3-T $\mathrm{AM}$-induced $\mathrm{Ca}^{2+}$ influx varies between normal and neoplastic cells, whereas no differences were detected in whole-cell current densities. This indicates that cytosolic $\mathrm{Ca}^{2+}$ regulation induced by $3-\mathrm{T}_{1} \mathrm{AM}$ might be partially independent from TRP activities. In the following chapter, we summarize the current knowledge about TRP involvement in 3-T $\mathrm{AM}$-induced $\mathrm{Ca}^{2+}$ mobilization and downstream signaling.

\section{Transient Receptor Potential Channels}

Transient receptor potential channels (TRPs) are a superfamily of membrane-spanning non-selective cation channels, which are mainly permeated by $\mathrm{Ca}^{2+}$. Classically, TRPs can trigger pain and reception to temperature via nociceptors. The TRP superfamily includes 28 members, which can be subdivided into six groups in mammals based on sequence homology (20) and sensitivity to activation by different stimuli: TRPA (ankyrin), TRPC (canonical), TRPM (melastatin), TRPML (mucolipin), TRPP (polycystic), and TRPV (vanilloid) [reviewed in Ref. $(21,22)]$.

TABLE 1 | 3-T 1 AM effects in different cell types.

\begin{tabular}{|c|c|c|c|c|}
\hline$\left[3-\mathrm{T}_{1} \mathrm{AM}\right](\mu \mathrm{M})$ & $\begin{array}{l}\text { Fluorescence ratio } \\
\qquad\left(f_{340 \mathrm{~nm}} / f_{380 \mathrm{~nm}}\right)\end{array}$ & Inward currents (pA/pF) & Outward currents (pA/pF) & Expression localization (cell type) \\
\hline 1.0 & $\uparrow \uparrow \uparrow \uparrow$ & $\mathrm{N} / \mathrm{A}$ & $\mathrm{N} / \mathrm{A}$ & TRPM8 transfected osteosarcoma [U2OS] (56) \\
\hline 1.0 & $\uparrow \uparrow \uparrow$ & N/A & N/A & Thyroid [PCCL3] (10) \\
\hline 1.0 & $\uparrow \uparrow$ & -15 & 108 & Human corneal epithelium [HCEC] (56) \\
\hline 1.0 & $\uparrow \uparrow$ & -22 & 161 & Human conjunctival epithelium [HCjEC] (17) \\
\hline 1.0 & $\uparrow$ & -25 & 170 & Neuroendocrine tumor [BON-1] (unpubl.) \\
\hline 5.0 & $\uparrow$ & -25 & 142 & Uveal melanoma [92.1] (unpubl.) \\
\hline
\end{tabular}

Fluorescent $\mathrm{Ca}^{2+}$ indicator fura-2 is alternately excited at 340 and $380 \mathrm{~nm}$, and the fluorescence ratio $\left(\mathrm{f}_{340 \mathrm{~nm}} / \mathrm{f}_{380 \mathrm{~nm}}\right)$ is a relative index of changes in [C $\left.\mathrm{C}^{2+}\right]$ i.

$\uparrow$ Slight increase, $\uparrow \uparrow$ moderate increase, $\uparrow \uparrow \uparrow$ strong increase, and $\uparrow \uparrow \uparrow \uparrow$ very strong increase.

3-T $A M$, 3-iodothyronamine: TRPM8, transient receptor potential channel melastatin 8. 
TRPs are located in the plasma membrane and the membrane of various organelles of most cell types. These channels mainly function as homo- and heterotetrameric structures $(23,24)$. They share the same basic topology, consisting of six transmembrane domains, a pore-forming loop and intracellular $\mathrm{N}$ and $\mathrm{C}$ termini. In some, but not all subfamilies, the $\mathrm{N}$ terminal domain contains ankyrin repeats, which contribute to channel assembly as well as gating and is a common protein-protein interaction motif $(25,26)$.

TRPs can be activated by thermal, mechanical, or chemical stimuli ranging from ions to small molecules. They are able to integrate and transduce them into appropriate responses in excitable and non-excitable cells $(27,28)$. There is also some evidence that TRP-elicited responses are modulated by their interactions with other receptors, such as GPCRs or ion channels in various healthy cell types as well as tumor cells (29-31).

\section{TRP/GPCR Interaction}

In mammals, GPCRs and TRPs are coexpressed in a variety of cell types; and different signaling intermediates, such as adaptor proteins, kinases and lipid metabolites, functionally link GPCRs to TRPs (32). TRPs are major downstream effectors of GPCRs, and the signaling pathways that emanate from the activation of GPCRs lead to altered TRP activity or expression $(22,33)$. Profound understanding of the intracellular $\mathrm{Ca}^{2+}$ signaling network, particularly the TRP/GPCR cross-talk and the substantial roles of TRPs, has significantly advanced the field of drug design and development $(33,34)$. One of the most studied GPCR/TRP regulatory pathways includes the bradykinin receptor (BR), which is coexpressed with TRPV1, TRP ankyrin receptor 1 (TRPA1), TRPM8, and TRPV4 in DRG nerve terminals. Activation of BR leads to rapid stimulation of TRPs to evoke action potentials, resulting in pain and inflammation $(32,35)$. Another example is coexpression and interaction of muscarinic receptors and TRPV1 in idiopathic overactive bladder urothelial cells, where the cells are responsive to both acetylcholine and capsaicin (36). Interestingly, 3- $\mathrm{T}_{1} \mathrm{AM}$ has been described as a novel antagonist of muscarinic type 3 receptor (37). Although further research on the potential pharmacological effects of $3-\mathrm{T}_{1} \mathrm{AM}$ in this context is necessary, this interesting example emphasizes the possibility of targeting the TRP/GPCR axis to develop new therapeutic options for different diseases.

\section{ROLE OF TRPS IN THERMOREGULATION}

Six members of the TRP superfamily are recognized as temperature-sensitive TRPs (thermo-TRPs), which are activated at specific temperatures in the range from noxious heat to painful cold (38). Thermo-TRPs are believed to be involved in body temperature perception and based on response patterns can be divided into two subtypes; namely, cold and heat receptors. TRPV1 and TRPV2 respond to painful increases in temperature, while TRPV3 and TRPV4 respond to non-painful increases in temperature. TRPM2 is known as the hypothalamic heat sensor, which mediates the responses to the temperature above $37^{\circ} \mathrm{C}$ and modulates fever temperature (39). TRPM8 is activated by non-painful decreases in temperature and TRPA1 by painful decrease in temperatures $(40,41)$. Thermo-TRPs are also substrates of chronic inflammatory mediators released in pathological pain states, which contribute to inflammatory responses and neuropathic pain (42-45). Recent studies demonstrated that TRPM8 and TRPV1 play homeostatic roles in temperature regulation (34).

TRPV1 is the most eminent member of TRP superfamily and has a broad distribution in central and peripheral nervous systems (46). Expression of TRPV1 also has been observed in non-excitable cells (47-49). Generally, TRPV1 can be activated by various stimuli such as heat, vanilloids, cannabinoids, lipids, and protons $(50,51)$. Administration of TRPV1 agonists triggers both increased heat loss and heat production in mammals (52).

TRP melastatin 8 is found on $\mathrm{A} \delta$ and $\mathrm{C}$ fiber afferents and is a major determinant of temperature homeostasis including autonomic thermogenesis (30). TRPM8 can be activated by moderate cooling as well as a variety of chemical agonists that are known to produce cool sensations such as menthol and icilin (53-55).

In general, thermo-TRPs can be activated within specific temperature ranges and transduce such inputs into chemical and electrical signals. Different chemical agents are identified which target these channels and elicit the similar downstream effects. So far, 3- $\mathrm{T}_{1} \mathrm{AM}$ is the only known endogenous compound inducing hypothermia and suggested to modulate thermo-TRPs as described in the following paragraph.

\section{3-T, $A M$ INTERACTS WITH THERMO-TRPS}

In a recent study, activation of warm-sensitive TRPM2 led to a similar thermoregulatory response observed in mice after systemic administration of 3-T $\mathrm{AM}(19,39)$. An electrophysiological screening of current densities in rat thyrocyte (PCCL3 cells) demonstrated the presence of thermo-TRPs in these cell lines. In PCCL3 cells, 3-T $\mathrm{T}$ AM induces $\mathrm{Ca}^{2+}$ responses similar to specific TRPM8 agonists such as menthol and icilin. Notably, $\mathrm{Ca}^{2+}$ elevation was exclusively attenuated in the presence of specific TRPM8 blocker (BCTC) in these cells, which strongly suggests $3-\mathrm{T}_{1} \mathrm{AM}$-induced $\mathrm{Ca}^{2+}$ rise is attributable to interactions with TRPM8 channels. Recent observations also confirmed the association between TRPM8 and 3- $\mathrm{T}_{1} \mathrm{AM}$ using an osteosarcoma heterologous expression system with overexpressed TRPM8 (56). Furthermore, many studies have demonstrated the endogenous expression of TRPs as well as adrenergic receptors in ocular tissues (17, 56-58). Interestingly, 3-T $\mathrm{AM}$ evoked $\mathrm{Ca}^{2+}$ mobilization and increases in whole-cell currents in human conjunctival and corneal epithelial cells. This increase in $\mathrm{Ca}^{2+}$ influx and in- and outward whole-cell currents were almost fully attenuated in the presence of TRPM8 antagonists $(10,17,56)$. Notably, the non-selective adrenergic receptor blocker timolol attenuated 3- $\mathrm{T}_{1} \mathrm{AM}$-induced $\mathrm{Ca}^{2+}$ effects in a similar manner to BCTC, which suggested that 3-T $\mathrm{T}$ AM activates TRPM8 downstream of GPCRs such as $\beta 2$ adrenergic receptors (7). Immunostaining pattern indicated TRPM8 expression in ER of ocular cells $(17,56)$. Previous studies also demonstrated TRPM8 localization in the ER membrane of a prostate cancer-derived epithelial cell line (LNCaP) $(59,60)$. Consequently, TRPM8 has been suggested as an important $\mathrm{ER} \mathrm{Ca}^{2+}$ release channel, which is involved in numerous processes in prostate cancer epithelial cells (60). Therefore, the persistence of 3-T $\mathrm{AM}$-induced $\mathrm{Ca}^{2+}$ influx in extracellular $\mathrm{Ca}^{2+}$ 
free conditions also might be attributable to intracellular TRPM8 expression in epithelial cells, which supports the hypothesis of 3- $\mathrm{T}_{1} \mathrm{AM}$-induced $\mathrm{Ca}^{2+}$ influx downstream of GPCRs.

Taken together, recent studies suggest that $3-\mathrm{T}_{1} \mathrm{AM}$ acts as a cooling agent similar to menthol or icilin. It has been proposed that 3-T $\mathrm{T}_{1} \mathrm{AM}$ may be a ligand of TRPM8; however, the evidence suggests that its cooling actions are primarily mediated via GPCR activation, which indirectly modulates TRPM8 activity. There is accumulating evidence that thermo-TRPs such as TRPM8 and TRPV1 are not only involved in physiological regulations but also a variety of pathophysiological conditions such as inflammation can be influenced by activation of these channels. Here, we describe the role of TRPs in inflammation and the potential of 3- $\mathrm{T}_{1} \mathrm{AM}$ as an anti-inflammatory agent.

\section{ROLE OF TRPS IN INFLAMMATION}

Different studies have demonstrated the role of TRPM8 in mediating the anti-inflammatory effects of mild cooling in traumainduced peripheral inflammation and limiting pain sensation after injury $(61,62)$. Menthol is one of the most commonly used phytochemical compounds in our daily life due to its analgesic benefit and its ability to provide a cooling sensation (63). Coexpression of TRPV1 with TRPM8 has been demonstrated in many different cell types $(64,65)$. It is known that multiple inflammatory signaling pathways can be activated downstream of TRPV1 activation by exogenous and endogenous stimuli $(66,67)$. Capsaicin as a specific TRPV1 agonist elicits increases in pro-inflammatory cytokine release via intracellular $\mathrm{Ca}^{2+}$ transients, which leads to interleukin secretion $(68,69)$. The interdependence of TRPM8 and TRPV1 ion channel function has raised interest in the field of anti-inflammatory therapeutic research $(70,71)$. Previous studies have shown that menthol blocks the mechanical and heat hyperalgesia caused by injection of inflammatory compounds, such as capsaicin $(72,73)$. Icilin is another specific TRPM8 agonist that is known as a "super-cooling" agent, with a notably higher potency and efficacy than menthol in cellular and behavioral studies (55). Icilin attenuates TRPV1-dependent calcitonin gene-related peptide release in the colon and is a promising therapeutic target for the treatment of colitis (71). Another study also suggested that downregulation of TRPM8 aggravates TRPV1-mediated inflammatory hyperalgesia (70). Although, the recent drug-screening efforts targeting TRPs have resulted in the discovery of effective TRPM8 agonists, the majority of these drugs either were not clinically efficacious or displayed adverse side effects. Subsequently, the general interest for introducing an effective and safe TRP modulator to suppress inflammatory symptoms in different tissues has increased. Recent studies demonstrated that $3-\mathrm{T}_{1} \mathrm{AM}$ has promising anti-inflammatory cooling properties similar to cooling agents such as icilin $(17,56)$.

\section{3-T, AM, A POSSIBLE THERAPEUTIC OPTION FOR INFLAMMATION?}

It has been well-established that TRPM8 activation leads to the suppression of TRPV1 stimulation $(70,71)$. Thus, we reviewed here the role of $3-T_{1} A M$ in this feedback system. Interestingly, an inverse association between changes in TRPM8 and TRPV1 activity after 3-T $\mathrm{T}_{1} \mathrm{AM}$ stimulation has been observed. Specifically, 3- $\mathrm{T}_{1} \mathrm{AM}$ blocked capsaicin-induced TRPV1 activation in human conjunctival and corneal epithelial cell lines and attenuated downstream rises in IL-6 release $(17,56)$. It was previously described that a TRPV1 antagonist elicited suppression of injury-induced stromal TRPV1 activation in corneal epithelium, which reduced inflammation and fibrosis (74). Notably, the blunting effects of 3-T $\mathrm{T}_{1} \mathrm{AM}$ on TRPV1-induced $\mathrm{Ca}^{2+}$ influx and IL-6 release mirrored the effects of TRPV 1 specific inhibitor $(17,56)$. This observation revealed a potential therapeutic value of $3-\mathrm{T}_{1} \mathrm{AM}$ for suppressing TRPV1-induced $\mathrm{Ca}^{2+}$ channel-mediated inflammatory processes in different pathophysiological conditions such as dry eye syndrome.

\section{CONCLUSION}

The $\mathrm{TH}$ derivative $3-\mathrm{T}_{1} \mathrm{AM}$ has been identified as a novel endogenous signaling compound exhibiting remarkable physiological effects such as hypothermia and hyperglycemia, as well as promising therapeutic potential in the experimental prophylaxis and treatment of stroke. Currently, the underlying mechanism of $3-\mathrm{T}_{1} \mathrm{AM}$ action and its physiological receptor(s) have been insufficiently characterized and are in need of further research. Here, we reviewed the $\mathrm{Ca}^{2+}$ signal transduction pathways induced by 3- $\mathrm{T}_{1} \mathrm{AM}$ and provided the promising evidence of TRP channel modulation through this $\mathrm{TH}$ metabolite (Figure 1). The $3-\mathrm{T}_{1} \mathrm{AM}$ action on GPCRs as well as on TRPs indicates the complex functional (co)-regulation of each system, which have a high impact on physiological and pathophysiological conditions. The close crosstalk of GPCRs and TRPs provides the opportunity to widen the options for therapeutic intervention, and by using such coregulated systems the possibility of unwanted side effects might be reduced.

\section{AUTHOR CONTRIBUTIONS}

$\mathrm{NK}$ and $\mathrm{HB}$ contributed to the conception, design, and drafting of this review. NK created the figure. SM created the table and contributed to the conception of this review. All the authors read and approved the final manuscript.

\section{ACKNOWLEDGMENTS}

The authors appreciate very much the input of Heiko Krude (Institute for Experimental Pediatric Endocrinology, Charite, University-Medicine Berlin) and his very helpful discussion. We thank the special support for editing the manuscript provided by Nicole Hallahan.

\section{FUNDING}

This work received a grant from the DFG priority program ThyroidTransAct (BI893/5-2). SM is supported by DFG (ME1706/14-1, ME1706/18-1) concerning TRP channel related research projects. 


\section{REFERENCES}

1. Scanlan TS, Suchland KL, Hart ME, Chiellini G, Huang Y, Kruzich PJ, et al. 3-Iodothyronamine is an endogenous and rapid-acting derivative of thyroid hormone. Nat Med (2004) 10(6):638-42. doi:10.1038/nm1051

2. Kleinau G, Khajavi N, Köhrle J, Biebermann H. Differential modulation of adrenergic receptor signaling by octopamine, tyramine, phenylethylamine, and 3-iodothyronamine. Trace Amines Neurol Disord (2016) 2:63. doi:10.1016/ B978-0-12-803603-7.00005-7

3. Piehl S, Hoefig C, Scanlan T, Köhrle J. Thyronamines - past, present, and future. Endocr Rev (2010) 32(1):64-80. doi:10.1210/er.2009-0040

4. Zucchi R, Chiellini G, Scanlan T, Grandy D. Trace amine-associated receptors and their ligands. Br J Pharmacol (2006) 149(8):967-78. doi:10.1038/ sj.bjp. 0706948

5. Zucchi R, Accorroni A, Chiellini G. Update on 3-iodothyronamine and its neurological and metabolic actions. Front Physiol (2014) 5:402. doi:10.3389/ fphys.2014.00402

6. Dinter J, Mühlhaus J, Jacobi SF, Wienchol CL, Cöster M, Meister J, et al. 3-Iodothyronamine differentially modulates $\alpha$-2A-adrenergic receptormediated signaling. J Mol Endocrinol (2015) 54(3):205-16. doi:10.1530/ JME-15-0003

7. Dinter J, Khajavi N, Mühlhaus J, Wienchol CL, Cöster M, Hermsdorf T, et al. The multitarget ligand 3-iodothyronamine modulates $\beta$-adrenergic receptor 2 signaling. Eur Thyroid J (2015) 4(Suppl 1):21-9. doi:10.1159/000381801

8. Klieverik LP, Foppen E, Ackermans MT, Serlie MJ, Sauerwein HP, Scanlan TS, et al. Central effects of thyronamines on glucose metabolism in rats. J Endocrinol (2009) 201(3):377-86. doi:10.1677/JOE-09-0043

9. Doyle KP, Suchland KL, Ciesielski TM, Lessov NS, Grandy DK, Scanlan TS, et al. Novel thyroxine derivatives, thyronamine and 3-iodothyronamine, induce transient hypothermia and marked neuroprotection against stroke injury. Stroke (2007) 38(9):2569-76. doi:10.1161/STROKEAHA.106.480277

10. Schanze N, Jacobi SF, Rijntjes E, Mergler S, del Olmo M, Hoefig CS, et al. 3-Iodothyronamine decreases expression of genes involved in iodide metabolism in mouse thyroids and inhibits iodide uptake in PCCL3 thyrocytes. Thyroid (2017) 27(1):11-22. doi:10.1089/thy.2016.0182

11. Laurent E, Mockel J, Van Sande J, Graff I, Dumont JE. Dual activation by thyrotropin of the phospholipase $\mathrm{C}$ and cyclic AMP cascades in human thyroid. Mol Cell Endocrinol (1987) 52(3):273-8. doi:10.1016/0303-7207(87)90055-4

12. Dumont JE, Willems C, Sande JV, Nève P. Regulation of the release of thyroid hormones: role of cyclic AMP. Ann N Y Acad Sci (1971) 185(1):291-316. doi: 10.1111/j.1749-6632.1971.tb45255.x

13. Grasberger H, Van SandeJ,Hag-Dahood Mahameed A, Tenenbaum-RakoverY, Refetoff S. A familial thyrotropin (TSH) receptor mutation provides in vivo evidence that the inositol phosphates/ $\mathrm{Ca}^{2+}$ cascade mediates TSH action on thyroid hormone synthesis. J Clin Endocrinol Metabol (2007) 92(7):2816-20. doi:10.1210/jc.2007-0366

14. Raspe E, Laurent E, Andry G, Dumont JE. ATP, bradykinin, TRH and TSH activate the $\mathrm{Ca}^{2+}$-phosphatidylinositol cascade of human thyrocytes in primary culture. Mol Cell Endocrinol (1991) 81(1):175-83. doi:10.1016/0303-7207(91)90216-F

15. Löf C, Sukumaran P, Viitanen T, Vainio M, Kemppainen K, Pulli I, et al. Communication between the calcium and cAMP pathways regulate the expression of the TSH receptor: TRPC2 in the center of action. Mol Endocrinol (2012) 26(12):2046-57. doi:10.1210/me.2012-1171

16. Kleinau G, Pratzka J, Nurnberg D, Gruters A, Fuhrer-Sakel D, Krude H, et al. Differential modulation of beta-adrenergic receptor signaling by trace amine-associated receptor 1 agonists. PLoS One (2011) 6(10):e27073. doi:10.1371/journal.pone.0027073

17. Khajavi N, Reinach PS, Slavi N, Skrzypski M, Lucius A, Strauß O, et al. Thyronamine induces TRPM8 channel activation in human conjunctival epithelial cells. Cell Signal (2015) 27(2):315-25. doi:10.1016/j.cellsig.2014.11.015

18. Panas HN, Lynch LJ, Vallender EJ, Xie Z, Chen GL, Lynn SK, et al. Normal thermoregulatory responses to 3 -iodothyronamine, trace amines and amphetamine-like psychostimulants in trace amine associated receptor 1 knockout mice. J Neurosci Res (2010) 88(9):1962-9. doi:10.1002/jnr.22367

19. Gachkar S, Oelkrug R, Martinez-Sanchez N, Rial-Pensado E, Warner A, Hoefig CS, et al. 3-Iodothyronamine induces tail vasodilation through central action in male mice. Endocrinology (2017) 158(6):1977-84. doi:10.1210/ en.2016-1951
20. Montell C. The TRP superfamily of cation channels. Sci Signal (2005) 2005(272):re3. doi:10.1126/stke.2722005re3

21. Ramsey IS, Delling M, Clapham DE. An introduction to TRP channels. Annu Rev Physiol (2006) 68:619-47. doi:10.1146/annurev.physiol.68.040204.100431

22. Clapham DE. TRP channels as cellular sensors. Nature (2003) 426(6966): 517-24. doi:10.1038/nature02196

23. Schaefer M. Homo-and heteromeric assembly of TRP channel subunits. Pflügers Archiv (2005) 451(1):35-42. doi:10.1007/s00424-005-1467-6

24. Huang C, Hu ZL, Wu WN, Yu DF, Xiong QJ, Song JR, et al. Existence and distinction of acid-evoked currents in rat astrocytes. Glia (2010) 58(12):1415-24. doi:10.1002/glia.21017

25. Phelps CB, Wang RR, Choo SS, Gaudet R. Differential regulation of TRPV1, TRPV3, and TRPV4 sensitivity through a conserved binding site on the ankyrin repeat domain. J Biol Chem (2010) 285(1):731-40. doi:10.1074/jbc. M109.052548

26. Sedgwick SG, Smerdon SJ. The ankyrin repeat: a diversity of interactions on a common structural framework. Trends Biochem Sci (1999) 24(8):311-6. doi:10.1016/S0968-0004(99)01426-7

27. Voets T. Quantifying and modeling the temperature-dependent gating of TRP channels. Rev Physiol Biochem Pharmacol (2012) 162:91-119. doi:10.1007/112_2011_5

28. Xu H, Ramsey IS, Kotecha SA, Moran MM, Chong JA, Lawson D, et al. TRPV3 is a calcium-permeable temperature-sensitive cation channel. Nature (2002) 418(6894):181-6. doi:10.1038/nature00882

29. Cordeiro S, Seyler S, Stindl J, Milenkovic VM, Strauss O. Heat-sensitive TRPV channels in retinal pigment epithelial cells: regulation of VEGF-A secretion. Invest Ophthalmol Vis Sci (2010) 51(11):6001-8. doi:10.1167/iovs.09-4720

30. Kobayashi K, Fukuoka T, Obata K, Yamanaka H, Dai Y, Tokunaga A, et al. Distinct expression of TRPM8, TRPA1, and TRPV1 mRNAs in rat primary afferent neurons with a $\delta / \mathrm{c}$-fibers and colocalization with trk receptors. J Comp Neurol (2005) 493(4):596-606. doi:10.1002/cne.20794

31. Mergler S, Cheng Y, Skosyrski S, Garreis F, Pietrzak P, Kociok N, et al. Altered calcium regulation by thermosensitive transient receptor potential channels in etoposide-resistant WERI-Rb1 retinoblastoma cells. Exp Eye Res (2012) 94(1):157-73. doi:10.1016/j.exer.2011.12.002

32. Pethő G, Reeh PW. Sensory and signaling mechanisms of bradykinin, eicosanoids, platelet-activating factor, and nitric oxide in peripheral nociceptors. Physiol Rev (2012) 92(4):1699-775. doi:10.1152/physrev.00048.2010

33. Veldhuis NA, Poole DP, Grace M, McIntyre P, Bunnett NW. The G protein-coupled receptor-transient receptor potential channel axis: molecular insights for targeting disorders of sensation and inflammation. Pharmacol Rev (2015) 67(1):36-73. doi:10.1124/pr.114.009555

34. Ahern GP. Transient receptor potential channels and energy homeostasis. Trends Endocrinol Metab (2013) 24(11):554-60. doi:10.1016/j.tem.2013.06.005

35. Wang S, Dai Y, Fukuoka T, Yamanaka H, Kobayashi K, Obata K, et al. Phospholipase $\mathrm{C}$ and protein kinase A mediate bradykinin sensitization of TRPA1: a molecular mechanism of inflammatory pain. Brain (2008) 131(5):1241-51. doi:10.1093/brain/awn060

36. Birder LA, Wolf-Johnston AS, Sun Y, Chai TC. Alteration in TRPV1 and muscarinic (M3) receptor expression and function in idiopathic overactive bladder urothelial cells. Acta Physiol (2013) 207(1):123-9. doi:10.1111/j.1748-1716.2012.02462.x

37. Laurino A, Matucci R, Vistoli G, Raimondi L. 3-Iodothyronamine (T1AM), a novel antagonist of muscarinic receptors. Eur J Pharmacol (2016) 793:35-42. doi:10.1016/j.ejphar.2016.10.027

38. Pan Z, Yang H, Reinach PS. Transient receptor potential (TRP) gene superfamily encoding cation channels. Hum Genomics (2011) 5(2):108. doi:10.1186/1479-7364-5-2-108

39. Song K, Wang H, Kamm GB, Pohle J, de Castro Reis F, Heppenstall P, et al. The TRPM2 channel is a hypothalamic heat sensor that limits fever and can drive hypothermia. Science (2016) 353(6306):1393-8. doi:10.1126/science.aaf7537

40. Dhaka A, Viswanath V, Patapoutian A. Trp ion channels and temperature sensation. Annu Rev Neurosci (2006) 29:135-61. doi:10.1146/annurev. neuro.29.051605.112958

41. Huang J, Zhang X, McNaughton PA, editors. Modulation of temperature-sensitive TRP channels. Semin Cell Dev Biol (2006) 17:638-45. doi:10.1016/j. semcdb.2006.11.002

42. Akbar A, Yiangou Y, Facer P, Walters JR, Anand P, Ghosh S. Increased capsaicin receptor TRPV1-expressing sensory fibres in irritable bowel syndrome and 
their correlation with abdominal pain. Gut (2008) 57(7):923-9. doi:10.1136/ gut.2007.138982

43. Engler A, Aeschlimann A, Simmen BR, Michel BA, Gay RE, Gay S, et al. Expression of transient receptor potential vanilloid 1 (TRPV1) in synovial fibroblasts from patients with osteoarthritis and rheumatoid arthritis. Biochem Biophys Res Commun (2007) 359(4):884-8. doi:10.1016/j.bbrc.2007.05.178

44. Yamamura H, Ugawa S, Ueda T, Morita A, Shimada S. TRPM8 activation suppresses cellular viability in human melanoma. Am J Physiol Cell Physiol (2008) 295(2):C296-301. doi:10.1152/ajpcell.00499.2007

45. Wondergem R, Bartley JW. Menthol increases human glioblastoma intracellular $\mathrm{Ca}^{2+}$, BK channel activity and cell migration. J Biomed Sci (2009) 16(1):90. doi:10.1186/1423-0127-16-90

46. Martins D, Tavares I, Morgado C. "Hotheaded": the role OF TRPV1 in brain functions. Neuropharmacology (2014) 85:151-7. doi:10.1016/j. neuropharm.2014.05.034

47. Akiba Y, Kato S, Katsube K-I, Nakamura M, Takeuchi K, Ishii H, et al. Transient receptor potential vanilloid subfamily 1 expressed in pancreatic islet $\beta$ cells modulates insulin secretion in rats. Biochem Biophys Res Commun (2004) 321(1):219-25. doi:10.1016/j.bbrc.2004.06.149

48. Mergler S, Garreis F, Sahlmüller M, Lyras E-M, Reinach PS, Dwarakanath A, et al. Calcium regulation by thermo- and osmosensing transient receptor potential vanilloid channels (TRPVs) in human conjunctival epithelial cells. Histochem Cell Biol (2012) 137(6):743-61. doi:10.1007/s00418-012-0924-5

49. Yang Y, Yang H, Wang Z, Mergler S, Wolosin JM, Reinach PS. Functional TRPV1 expression in human corneal fibroblasts. Exp Eye Res (2013) 107:121-9. doi:10.1016/j.exer.2012.11.004

50. Fernandes E, Fernandes M, Keeble J. The functions of TRPA1 and TRPV1: moving away from sensory nerves. Br J Pharmacol (2012) 166(2):510-21. doi:10.1111/j.1476-5381.2012.01851.x

51. Pingle S, Matta J, Ahern G. Capsaicin receptor: TRPV1 a promiscuous TRP channel. Handb Exp Pharmacol (2007) 179:155-71. doi:10.1007/978-3-540-34891-7_9

52. Kobayashi A, Osaka T, Namba Y, Inoue S, Lee TH, Kimura S. Capsaicin activates heat loss and heat production simultaneously and independently in rats. Am J Physiol (1998) 275(1):R92-8.

53. Behrendt HJ, Germann T, Gillen C, Hatt H, Jostock R. Characterization of the mouse cold-menthol receptor TRPM8 and vanilloid receptor type-1 VR1 using a fluorometric imaging plate reader (FLIPR) assay. Br J Pharmacol (2004) 141(4):737-45. doi:10.1038/sj.bjp.0705652

54. Dai Y. TRPs and pain. Semin Immunopathol (2016) 38(3):277-91. doi:10.1007/ s00281-015-0526-0

55. McKemy DD, Neuhausser WM, Julius D. Identification of a cold receptor reveals a general role for TRP channels in thermosensation. Nature (2002) 416(6876):52-8. doi:10.1038/nature719

56. Lucius A, Khajavi N, Reinach PS, Köhrle J, Dhandapani P, Huimann P, et al. 3-Iodothyronamine increases transient receptor potential melastatin channel 8 (TRPM8) activity in immortalized human corneal epithelial cells. Cell Signal (2016) 28(3):136-47. doi:10.1016/j.cellsig.2015.12.005

57. Matsuo T, Cynader MS. Localization of alpha-2 adrenergic receptors in the human eye. Ophthalmic Res (1992) 24(4):213-9. doi:10.1159/000267170

58. Neufeld AH, Zawistowski K, Page ED, Bromberg BB. Influences on the density of beta-adrenergic receptors in the cornea and iris-ciliary body of the rabbit. Invest Ophthalmol Vis Sci (1978) 17(11):1069-75.

59. Zhang L, Barritt GJ. Evidence that TRPM8 is an androgen-dependent $\mathrm{Ca}^{2+}$ channel required for the survival of prostate cancer cells. Cancer Res (2004) 64(22):8365-73. doi:10.1158/0008-5472.Can-04-2146

60. Thebault S, Lemonnier L, Bidaux G, Flourakis M, Bavencoffe A, Gordienko D, et al. Novel role of cold/menthol-sensitive transient receptor potential melastatine family member 8 (TRPM8) in the activation of store-operated channels in LNCaP human prostate cancer epithelial cells. J Biol Chem (2005) 280(47):39423-35. doi:10.1074/jbc.M503544200

61. Harrington AM, Hughes PA, Martin CM, Yang J, Castro J, Isaacs NJ, et al. A novel role for TRPM8 in visceral afferent function. Pain (2011) 152(7): 1459-68. doi:10.1016/j.pain.2011.01.027

62. Proudfoot CJ, Garry EM, Cottrell DF, Rosie R, Anderson H, Robertson DC, et al. Analgesia mediated by the TRPM8 cold receptor in chronic neuropathic pain. Curr Biol (2006) 16(16):1591-605. doi:10.1016/j.cub.2006.07.061

63. Eccles R. Menthol and related cooling compounds. J Pharm Pharmacol (1994) 46(8):618-30. doi:10.1111/j.2042-7158.1994.tb03871.x

64. Crawford DC, Moulder KL, Gereau RW IV, Story GM, Mennerick S. Comparative effects of heterologous TRPV1 and TRPM8 expression in rat hippocampal neurons. PLoS One (2009) 4(12):e8166. doi:10.1371/journal. pone. 0008166

65. Lin M-J, Yang X-R, Cao Y-N, Sham JS. Hydrogen peroxide-induced $\mathrm{Ca}^{2+}$ mobilization in pulmonary arterial smooth muscle cells. Am J Physiol Lung Cell Mol Physiol (2007) 292(6):L1598-608. doi:10.1152/ajplung.00323.2006

66. Assas B, Miyan J, Pennock J. Cross-talk between neural and immune receptors provides a potential mechanism of homeostatic regulation in the gut mucosa. Mucosal Immunol (2014) 7(6):1283-9. doi:10.1038/mi.2014.80

67. Huang W-X, Yu F, Sanchez RM, Liu Y-Q, Min J-W, Hu J-J, et al. TRPV1 promotes repetitive febrile seizures by pro-inflammatory cytokines in immature brain. Brain Behav Immun (2015) 48:68-77. doi:10.1016/j.bbi.2015.01.017

68. Tominaga M, Numazaki M, Iida T, Moriyama T, Togashi K, Higashi T, et al. Regulation mechanisms of vanilloid receptors. Pathol Pain (2004) 4:4-12. doi:10.1002/0470869127.ch2

69. Li D-Q, Luo L, Chen Z, Kim H-S, Song XJ, Pflugfelder SC. JNK and ERK MAP kinases mediate induction of IL-1 $1 \beta$, TNF- $\alpha$ and IL-8 following hyperosmolar stress in human limbal epithelial cells. Exp Eye Res (2006) 82(4):588-96. doi:10.1016/j.exer.2005.08.019

70. Premkumar LS, Raisinghani M, Pingle SC, Long C, Pimentel F. Downregulation of transient receptor potential melastatin 8 by protein kinase C-mediated dephosphorylation. J Neurosci (2005) 25(49):11322-9. doi:10.1523/ JNEUROSCI.3006-05.2005

71. Ramachandran R, Hyun E, Zhao L, Lapointe TK, Chapman K, Hirota CL, et al. TRPM8 activation attenuates inflammatory responses in mouse models of colitis. Proc Natl Acad Sci U S A (2013) 110(18):7476-81. doi:10.1073/ pnas. 1217431110

72. Pan R, Tian Y, Gao R, Li H, Zhao X, Barrett JE, et al. Central mechanisms of menthol-induced analgesia. J Pharmacol Exp Ther (2012) 343(3):661-72. doi:10.1124/jpet.112.196717

73. Alpizar YA, Boonen B, Gees M, Sanchez A, Nilius B, Voets T, et al. Allyl isothiocyanate sensitizes TRPV1 to heat stimulation. Pflügers Arch (2014) 466(3):507-15. doi:10.1007/s00424-013-1334-9

74. Zhang F, Yang H, Wang Z, Mergler S, Liu H, Kawakita T, et al. Transient receptor potential vanilloid 1 activation induces inflammatory cytokine release in corneal epithelium through MAPK signaling. J Cell Physiol (2007) 213(3):730-9. doi:10.1002/jcp.21141

Conflict of Interest Statement: The authors declare that the research was conducted in the absence of any commercial or financial relationships that could be construed as a potential conflict of interest.

Copyright $\odot 2017$ Khajavi, Mergler and Biebermann. This is an open-access article distributed under the terms of the Creative Commons Attribution License (CC BY). The use, distribution or reproduction in other forums is permitted, provided the original author(s) or licensor are credited and that the original publication in this journal is cited, in accordance with accepted academic practice. No use, distribution or reproduction is permitted which does not comply with these terms. 